\title{
Public-private partnership as a mechanism for the development of heat supply
}

\author{
Aleksey Bataev ${ }^{1, *}$, Dmitry Samorukov ${ }^{2}$, Antonina Glushkova ${ }^{3}$ and Vitaly Potyarkin ${ }^{2}$ \\ ${ }^{1}$ Peter the Great St.Petersburg Polytechnic University, 195251 St. Petersburg, Russia \\ ${ }^{2}$ National Technology Initiative Center for Advanced Manufacturing Technologies based \\ on the Institute of Advanced Manufacturing Technologies of Peter the Great St. \\ Petersburg Polytechnic University Polytechnicheskaya, 29, St.Petersburg, 195251, Russia \\ ${ }^{3}$ Samara National Research University, 34, Moskovskoye shosse, Samara, 443086, Russia
}

\begin{abstract}
The relevance of the research topic is caused by the need to form new innovative approaches in the field of heat supply, aimed at modernizing thermal power plants that provide heat to urban areas. In recent years, the Russian government has adopted several state programs related to environmental protection, directed towards reducing the emission of harmful substances into the atmosphere. Thermal power plants are objects whose emissions significantly pollute the environment. Considering the wear of equipment, according to various estimates, reaches $60-80 \%$ in different regions, such equipment is extremely necessary to be modernized. Using the mechanism of public-private partnership in the field of heat supply is examined in this study. An algorithm for constructing a model in the field of creating mini thermal power plants is considered. They provide heat supply to individual urban areas, as well as to ensure a significant reduction in the level of environmental pollution. The main financial indicators are estimated based on the above algorithm. This project's performance is assessed on the basis of financing both from the state and private companies. Conclusions about using the proposed model for the development of heat supply are drawn.
\end{abstract}

Keywords: natural resource management, energy, sustainable development, public-private partnership mechanism, financial analysis, heat supply, mini thermal power plants, investments

\section{Introduction}

In the field of heat supply, there are some problems that can be solved by using the mechanism of public-private partnership. The following problems can be distinguished: the wear and tear of fixed assets of public utilities approach to $60 \%$, it reaches $80 \%$ in some regions; the share of losses and unaccounted consumption in the total volume of produced heat energy is about 30\%; investment demand (reducing the share of networks that need

\footnotetext{
*Corresponding author: bat_a68@mail.ru
} 
replacement, providing centralized heat supply services) - 2 trillion rubles; annual investments in the sector do not exceed 100 billion rubles; external sources of financing (loans, equity) account for only 10-15\%. [1] The problems of attracting investments are the inability of private operators to predict future revenues, which is caused by regulatory risks. [2] The mechanism of public-private partnership ensures the formation of innovative approaches in the field of creating new heat supply facilities reducing the negative impact on the environment, while ensuring sustainable financing in their creation.

\section{$2 \quad$ Materials and methods}

In this study, the method of investment analysis was applied, representing a set of tools and actions that determine the attractiveness and forecast the amount of profitability of investment in the selected project. [3] Based on the proposed method, an investment project was assessed to create mini thermal power plants within a public-private partnership mechanism.

\section{Results and discussion}

When a mini-thermal power plant facility is put into power supply systems, there is no need to build distribution networks to connect new consumers, and, accordingly, the amount of required investments in the development of networks is reduced. [4] Capital investments in the construction of distribution networks are determined on the basis of design and estimate documentation in each specific case. The aggregated cost indicators of the construction of overhead and cable lines and transformer substations can be used to assess this systemic effect. Saving capital investments in distribution networks during the construction of small distributed power supply (MDPS) facilities is determined by the formula (1):

where

$$
\Delta K_{t}^{n w}=k_{o} \times l_{o}+k_{c} \times l_{c}+k_{s} \times \mathrm{m}
$$

$\Delta K_{t}^{n w}$ - saving capital investments in the development of distribution networks when entering objects MDPS into the regional energy system;

$k_{o}, l_{o}$ - specific capital investments in the construction of $1 \mathrm{~km}$ of overhead and cable lines, respectively, $\mathrm{P} / \mathrm{km}$;

$k_{c}, l_{c}-$ the length of overhead and cable lines (respectively) from a centralized power source to consumers, $\mathrm{km}$;

$k_{s}$ - specific capital investments in the construction of one substation, $\mathrm{P} / \mathrm{un}$;

$m$ - the number of substations in the distribution network, un.

The volume of reducing the necessary investments in the development of distribution networks of the regional energy system depends on many factors:

- the structure in terms of thermal capacity and geographic location of boiler plants in the municipalities in the region;

- the structure by size and territorial distribution of electric loads of consumers;

- the structure by voltage and length of electrical distribution networks. [5-6]

In this case, for assessing the economic effect associated with reducing the cost of developing electrical distribution networks, a mathematical model is necessary to create and optimize that would provide the best result when building the required network configuration. [7] In the mathematical model under consideration, under the existing growth rates of electrical loads caused by the connection of new consumers in the region and possible options for modernizing existing thermal power plants with and without their transition to cogeneration facilities, optimization of both the circuit and the main values of 
the network connection parameters can be carried out. The parameters of transformer substations should also be optimized according to the main criterion aimed at obtaining a minimum of the total value of investments in electrical networks, with a planning period of 10-15 years. This would ensure optimal financing of heat supply. [8-10]

When mini-TPPs are launched, the undersupply of electricity to consumers will decrease by 15.34 million $\mathrm{kW} \cdot \mathrm{h} /$ year or $12 \%$ due to increased reliability of the power supply. According to the methodological recommendations for the design of the development of power systems, developed by JSC "Institute" Energosetproekt ", the specific damage will be $50-150 \mathrm{r} / \mathrm{kW} \cdot \mathrm{h}$. Then the introduction of mini-TPP into the regional energy system would reduce the damage from undersupply of energy by 767-2301 million rubles/year. Losses during transmission of electricity in the network will decrease by $39.08 \mathrm{MW}$ or $14 \%$, taking into account the number of hours of maximum losses in the amount of 2500 hours and the weighted average price of the wholesale market of 2.5 $\mathrm{r} / \mathrm{kW} \cdot \mathrm{h}$. The cost of compensation for losses during transmission when commissioning MDPS facilities will decrease by 244.3 million rubles/year (prices of 2019). On the basis of the obtained results of systemic effects during the commissioning of mini-TPPs, the indicators of specific effects from the commissioning of MDPS facilities in the networks and at consumers were evaluated (Table 1). [11-12]

Table 1. Specific effects of entering MDPS objects

\begin{tabular}{|c|c|c|c|}
\hline Name & $\begin{array}{c}\text { Reduction } \\
\text { load limits, MW }\end{array}$ & $\begin{array}{c}\text { Reduction } \\
\text { undersupply of } \\
\text { electricity, million } \\
\mathrm{kW} \cdot \mathrm{h} / \mathrm{MW}\end{array}$ & $\begin{array}{c}\text { Decrease } \\
\text { power losses in the } \\
\text { network, MW }\end{array}$ \\
\hline $\begin{array}{c}\text { Specific indicators of } \\
\text { small TPPs with } \\
\text { cogeneration }\end{array}$ & 0,0006 & 0,0239 & 0,0609 \\
\hline
\end{tabular}

An integral estimate of the systemic effect of reducing investment in distribution networks was carried out on the basis of the $6-10-35 \mathrm{kV}$ distribution network model. It ranged from 2 to 5 thousand rubles per $1 \mathrm{~kW}$ of installed capacity of MDPS facilities. When the estimated cost is $1 \mathrm{~kW}$ of the MDPS facility of about $\$ 1000$ or 76 thousand rubles $/ \mathrm{kW}$, the indicated values from this type of systemic effect are $4-8 \%$ of the specific investment per $1 \mathrm{~kW}$ of the MDPS facility. The model was used to create a mini-TPP by the mechanism of publicprivate partnership.

The construction of mini-TPP is carried out by attracting funds from a leasing company with their further return on the basis of a leaseback scheme. In this study, the payment under the main lease agreement is suggested in equal installments. The number of lease payments and the schedule of payments is determined according to the lease agreement:

- project cost - 424270000 rubles;

- leasing term -48 months;

- the contractual payment is made in equal monthly installments;

- The amount of the leasing company's annual cost premium is assumed to be $10 \%$ of the project cost.

For analyzing the mini-TPP construction performance, the project's economic efficiency was evaluated based on the enlarged financial model using the forecast prices necessary for the correct calculation of the main parameters of the project: the level of costs, the level of tariffs, cash flows for the project, etc. The payback period of the project and the amount of profit that can be obtained by the investor from this investment project was defined based on the assessment of the net present value, which is as follows (2): 
where

$$
N P V=\sum_{t=0}^{T} \frac{C F_{t}}{\prod_{i=0}^{t}\left(1+r_{i}\right)}-\sum_{t=0}^{t} \frac{I_{t}}{\prod_{i=0}^{t}\left(1+r_{i}\right)}
$$

$\mathrm{T}$ - the number of planned time intervals for the implementation of the information project,

$\mathrm{CF}_{\mathrm{t}}$ - cash flow during a time period $\mathrm{t}$,

$\mathrm{I}_{\mathrm{t}}$ - investment in the project during a time period $\mathrm{t}$,

$\mathrm{r}$ - discount rate.

Estimations are shown in tables 2 and 3.

Table 2. Cash flow of mini-thermal power plants from 2021 to 2026

\begin{tabular}{|c|c|c|c|c|c|c|}
\hline Indicator, thousand rubles & 2021 & 2022 & 2023 & 2024 & 2025 & 2026 \\
\hline $\begin{array}{c}\text { 1. Revenue from the sale } \\
\text { of thermal energy }\end{array}$ & 130945 & 137492 & 144367 & 151585 & 159164 & 167123 \\
\hline $\begin{array}{c}\text { 2. Production costs, } \\
\text { including }\end{array}$ & 212836 & 215884 & 219085 & 222445 & 109299 & 113004 \\
\hline 2.1. Fuel & 60122 & 63128 & 66285 & 69599 & 73079 & 76733 \\
\hline 2.2 Repairs and service & 194 & 204 & 214 & 225 & 236 & 248 \\
\hline 2.3 Amortization & 21214 & 21214 & 21214 & 21214 & 21214 & 21214 \\
\hline 2.4. Main personnel & 13987 & 13987 & 13987 & 13987 & 13987 & 13987 \\
\hline 2.5.Unexpected expenses & 645 & 677 & 711 & 747 & 784 & 823 \\
\hline 2.6. Lease payments & 116675 & 116675 & 116675 & 116675 & - & - \\
\hline 3. Gross profit & -81891 & -78392 & -74718 & -70860 & 49865 & 54119 \\
\hline Income tax & 0 & 0 & 0 & 0 & 7230 & 7847 \\
\hline Net profit/loss & -81891 & -78392 & -74718 & -70860 & 42635 & 46272 \\
\hline Cash flow & -60678 & -57179 & -53504 & -49647 & 63848 & 67485 \\
\hline Cumulative CF & -60678 & -117856 & -171361 & -221007 & -157159 & -89674 \\
\hline
\end{tabular}

Table 3. Cash flow of mini-thermal power plants from 2027 to 2032

\begin{tabular}{|c|c|c|c|c|c|c|}
\hline Indicator, thousand rubles & 2027 & 2028 & 2029 & 2030 & 2031 & 2032 \\
\hline $\begin{array}{c}\text { 1. Revenue from the sale } \\
\text { of thermal energy }\end{array}$ & 175479 & 184253 & 193465 & 203139 & 213296 & 223960 \\
\hline $\begin{array}{c}\text { 2. Production costs, } \\
\text { including }\end{array}$ & 116894 & 120979 & 125268 & 129771 & 134500 & 139464 \\
\hline 2.1. Fuel & 80569 & 84598 & 88828 & 93269 & 97932 & 102829 \\
\hline 2.2 Repairs and service & 260 & 273 & 287 & 301 & 316 & 332 \\
\hline 2.3 Amortization & 21214 & 21214 & 21214 & 21214 & 21214 & 21214 \\
\hline 2.4. Central personnel & 13987 & 13987 & 13987 & 13987 & 13987 & 13987 \\
\hline 2.5. Unexpected expenses & 864 & 908 & 953 & 1001 & 1051 & 1103 \\
\hline 2.6. Lease payments & - & - & - & - & - & - \\
\hline 3. Gross profit & 58585 & 63274 & 68198 & 73368 & 78796 & 84496 \\
\hline Income tax & 8495 & 9175 & 9889 & 10638 & 11425 & 12252 \\
\hline Net profit/loss & 50090 & 54099 & 58309 & 62729 & 67371 & 72244 \\
\hline Cash flow & 71303 & 75313 & 79523 & 83943 & 88584 & 93457 \\
\hline Cumulative CF & -18370 & 56942 & 136465 & 220408 & 308992 & 402449 \\
\hline
\end{tabular}

Net present value during the first 12 years of the project is presented below in Table 4 .

Table 4. Net present value of mini-thermal power plants from 2021 to 2032

\begin{tabular}{|c|c|}
\hline Period number (year) & NPV value, thousand rubles \\
\hline 1 & $-55161,64$ \\
\hline 2 & $-102416,68$ \\
\hline 3 & $-142615,36$ \\
\hline 4 & $-176524,63$ \\
\hline
\end{tabular}




\begin{tabular}{|c|c|}
\hline 5 & $-136879,74$ \\
\hline 6 & $-98786,18$ \\
\hline 7 & $-62196,23$ \\
\hline 8 & $-27062,26$ \\
\hline 10 & 6663,07 \\
\hline 11 & 39026,67 \\
\hline 12 & 70074,87 \\
\hline
\end{tabular}

Besides, let us consider the indicators that identify the investment attractiveness of this project (Table 5).

Table 5. Investment attractiveness indicators

\begin{tabular}{|c|c|}
\hline Indicator & Value \\
\hline Average rate of profit & $2,64 \%$ \\
\hline Payback period & 7,2 years \\
\hline Return on investment index & 1,62 \\
\hline Net present value for 12 years & 99853,3 thousand rubles \\
\hline Discounted return on investment & 1,3 years \\
\hline Discounted return index & 1,34 \\
\hline
\end{tabular}

The results obtained through the analysis of economic efficiency showed that the cost of the heat production process would exceed the amount of revenue within four years from the start of the project. Due to the connection with the fulfillment of its obligations under the main lease agreement, the situation changes after the transfer of objects into the ownership of the investor and the completion of lease payments by the leasing company. Starting in 2025 , the cost of heat production would be significantly lower than revenue. As a result, the discounted payback period would be 8.8 years (at a discount rate of $10 \%$ ).

\section{Conclusion}

Having analyzed data, the following conclusions can be drawn:

1. Because of the poor technical condition of the objects that are part of the heat supply facilities, there is an acute issue of low productivity, low efficiency of capacities, and a fixed large loss of energy carriers.

2. It should be noted that public-private partnership is the optimal solution to the modernization problem of utility and energy facilities that is important for the country.

3. The following main results of the made changes must be noted:

- reduction of heat energy loss;

- replacement of old equipment with more economical ones.

The main economic effect from the modernization of the existing heat supply system is achieved due to:

- reduction of heat energy losses in heating networks;

- replacement of old equipment with more cost-effective ones.

\section{References}

1. Karuseva, N., Livshits, S., Kotsubinski, A., Yudina, N., Novikova, O., \& Tabakova, A. (2019). The impact of innovative technologies on consumers in the power supply market. Paper presented at the E3S Web of Conferences, , 140 doi:10.1051/e3sconf/201914004009 
2. Polyukhovich, M., Burlov, V., Mankov, V., \& Bekbayev, A. (2019). Electric power supply management of the construction site in the interests of facilitating electrical safety. Paper presented at the E3S Web of Conferences, , 140 doi:10.1051/e3sconf/201914008006

3. Davydov, V., Fadeenko, V., Fadeenko, I., Reznik, V., Kruglov, V., Popovskiy, N., \& Rud, V. (2019). Multifunctional method for remote monitoring of the environment in the area of nuclear facilities. Paper presented at the E3S Web of Conferences, , 140 doi:10.1051/e3sconf/201914007006

4. Egorova, S., Bogdanovich, I., Kistaeva, N., \& Kulachinskaya, A. (2019). Environmental costs as an indicator of sustainable development. Paper presented at the E3S Web of Conferences, , 140 doi:10.1051/e3sconf/201914009007

5. Sukhareva, E., Fedyukhin, A. V., Kikot, E. A., Matisov, B. G., Nikitkov, N. V., Izrantsev, V. V., . . . Sinitsyn, A. A. (2019). Flexible allocation of costs between electricity and heat as a factor for improving the CHP competitiveness. Paper presented at the IOP Conference Series: Earth and Environmental Science, , 337(1) doi:10.1088/1755-1315/337/1/012079

6. Treshcheva, M., Treshchev, D., Anikina, I., \& Skulkin, S. (2019). The potential for reducing TPP water consumption through the use of heat pumps. Paper presented at the E3S Web of Conferences, , 140 doi:10.1051/e3sconf/201914011001

7. Elgamal, M., Korovkin, N. V., Refaat, A., \& Elmitwally, A. (2019). Optimal operation of a hybrid-energy microgrid with energy storage system. Paper presented at the E3S Web of Conferences, , 138 doi:10.1051/e3sconf/201913801003

8. Gamayunova, O., \& Golov, R. (2019). Potential of energy saving on transport. Paper presented at the E3S Web of Conferences, , 135 doi:10.1051/e3sconf/201913502025

9. Velmakina, Y. V., Vasiliev, V. A., \& Chernogorskiy, S. A. (2019). Integrated management systems as a basis for sustainable development of the organization. Paper presented at the IOP Conference Series: Materials Science and Engineering, , 666(1) doi:10.1088/1757-899X/666/1/012041

10. Gryznova, E., Davydov, V., Batov, Y., Dudkin, V., Puz'ko, D., Myazin, N., \& Rud, V. (2019). Methodology for assessing the environmental characteristics of various methods of generating electricity. Paper presented at the E3S Web of Conferences, , 140 doi:10.1051/e3sconf/201914009001

11. Radushinskaya, A., Pushkina, M., Antonova, A., Morozova, S., Dyakova, G., \& Gaganova, E. (2019). Investment priorities and investment potential of various infrastructure facilities of the city. Paper presented at the E3S Web of Conferences, , 135 doi:10.1051/e3sconf/201913504055

12. Sadeghi, K., Ghazaie, S. H., Sokolova, E., Fedorovich, E., \& Shirani, A. (2019). Thermo-economic assessment of the possible desalination processes for the second block of bushehr nuclear power plant. Paper presented at the E3S Web of Conferences, , 140 doi:10.1051/e3sconf/201914003001 